\title{
Contributions of Cladistic Biogeography to the Mexican Transition Zone
}

\author{
Isolda Luna-Vega ${ }^{1, *}$ and Raúl Contreras-Medina ${ }^{2}$ \\ ${ }^{1}$ Laboratorio de Biogeografía y Sistemática, Departamento de Biología Evolutiva, \\ Facultad de Ciencias, Universidad Nacional Autónoma de México (UNAM), \\ ${ }^{2}$ Escuela de Ciencias, Universidad Autónoma "Benito Juárez" de Oaxaca (UABJO), \\ México
}

\section{Introduction}

The Mexican Transition Zone (MTZ) was defined by Halffter (1987) as the complex area where Neotropical and Nearctic biotic elements overlap, including the southern United States, Mexico and adjacent areas of Central America. The biota of this area has received the attention of several naturalists since the mid 19th century (e.g. Sclater, 1858) due to its placement between the Nearctic and Neotropical regions and its "hybrid" character (Morrone, 2005 and references therein), associated with high biotic diversity and a high degree of endemism of plant and animal taxa. This area also has received attention in conservation and biodiversity plans at a worldwide level, because its central portion, the Mesoamerican hotspot, was considered one of the main biodiversity hotspots recognized in the world (Flores-Villela \& Gerez, 1994; Luna-Vega and Contreras-Medina, 2010; Mittermeier et al., 1998; Myers et al., 2000).

Recently, authors have proposed hypotheses to explain disjunct biotic patterns observed in the MTZ from different approaches and methodologies, such as panbiogeography (Álvarez \& Morrone, 2004; Contreras-Medina \& Eliosa-León, 2001; Escalante et al., 2004; Morrone \& Márquez, 2001; Morrone \& Gutiérrez, 2005), parsimony analysis of endemicity (AguilarAguilar et al., 2003; Espinosa et al., 2000; Luna-Vega et al., 2001; Morrone et al., 1999; Morrone \& Escalante, 2002), and cladistic biogeography (Contreras-Medina et al., 2007; Espinosa et al., 2006; Flores-Villela \& Goyenechea, 2001; Liebherr, 1991; Marshall \& Liebherr, 2000; Rosen, 1978). The latest studies based on cladistic biogeography approaches represent the basis of this chapter.

Our goal here is to compare and discuss the different contributions made to the biogeography of the Mexican Transition Zone by applying different cladistic biogeographical methods. It is also to contrast the different areas of endemism proposed in these studies with the objective of obtaining consensus on areas of endemism to be considered in future research.

${ }^{*}$ Corresponding Author 


\section{Cladistic biogeography: Basis and methods}

Cladistic biogeography is an approach to historical biogeography that searches for patterns of relationships among areas of endemism based on the phylogenetic relationships of the taxa inhabiting them (Crisci et al., 2000; Humphries \& Parenti, 1999; Morrone \& Crisci, 1995). This approach emerged as a combination of principles of phylogenetic systematics of Willi Hennig (1966) and the biogeographic ideas formulated by Léon Croizat $(1958,1964)$ represented in his book Panbiogeography (Contreras-Medina, 2006; Craw, 1988; Crisci et al., 2000; Espinosa \& Llorente, 1993; Flores-Villela \& Goyenechea, 2001). Cladistic biogeography is based on a close relationship among systematics and biogeography, considering that taxonomic cladograms converted into area cladograms can elucidate the fragmentation sequence of studied areas. With this procedure, it is possible to propose hypotheses on historical relationships among areas of endemism (Contreras-Medina, 2006; Morrone, 1997). Cladistic biogeographic analysis essentially looks for congruent patterns among area cladograms of different taxa (Humphries \& Parenti, 1999; Page \& Lydeard, 1994) showed in a general area cladogram, which represents the final result of this kind of analysis (Contreras-Medina, 2006; Morrone, 1997). Interpretation of cladistic biogeographical results usually focuses on vicariance rather than on dispersal events, because vicariance affects different groups of organisms simultaneously (Morrone \& Crisci, 1995; Nelson \& Platnick, 1981).

The construction of area cladograms is simple when each taxon is endemic to a single area and each area has only one taxon (Morrone, 1997). Incongruence can occur between two or more area cladograms due to three main reasons, known as redundant distributions, widespread taxa and missing areas (Morrone et al., 1996). Redundant distributions occur when an area appears more than once in an area cladogram, because two or more terminal taxa are distributed in this area; widespread taxa occur when any of the terminal taxa inhabits two or more of the areas analyzed; missing areas occur when there is not a terminal taxon distributed in one of the areas analyzed, therefore this area is not represented in the area cladograms (Morrone, 2009). One or more of the methods that have been proposed in cladistic biogeography are then applied to these area cladograms, and the final result is a general area cladogram (Morrone, 1997).

The first method developed in cladistic biogeography was the reduced consensus cladogram proposed by Rosen (1978), which was only used by him. Another method proposed was the Brooks parsimony analysis or BPA (Brooks, 1990; Kluge, 1988), which has been extensively used in studies developed in the MTZ (Contreras-Medina et al., 2007; Espinosa et al., 2006; Marshall \& Liebherr, 2000). BPA has been criticized by some authors as a suboptimal method, because it uses both dispersal and vicariance explanations to fit taxa and areas to the same tree (e.g. Siddall \& Perkins, 2003); however, other authors (e.g. Brooks et al., 2001; Van Veller \& Brooks, 2001) have defended it as a valid method. Nelson \& Ladiges (1996) noted that when nodes and areas are associated in order to be included in a data matrix, geographic paralogy may result because of duplication or overlap in the distribution of taxa related by paralogous nodes. To this end, another method was proposed, known as paralogy-free subtrees (Nelson \& Ladiges, 1995). This method consists in the reduction of complex cladograms to paralogy-free-subtrees, that means that geographic data are associated only with the informative nodes, and areas duplicated or redundant in the descendants of each node do not exist (Morrone, 2009). Once that paralogy-free-subtrees are 
obtained, these are represented in a component or a three-item matrix and analyzed with a parsimony algorithm (Crisci et al., 2000). A parsimony analysis of these paralogy-free subtrees (PAPS) may thus be used to generate a more robust hypothesis, because geographic paralogy has been removed. Another frequent method that has been cited in biogeographic literature is component analysis (Nelson \& Platnick, 1981), but unfortunately this method has not been applied to the biota of the MTZ.

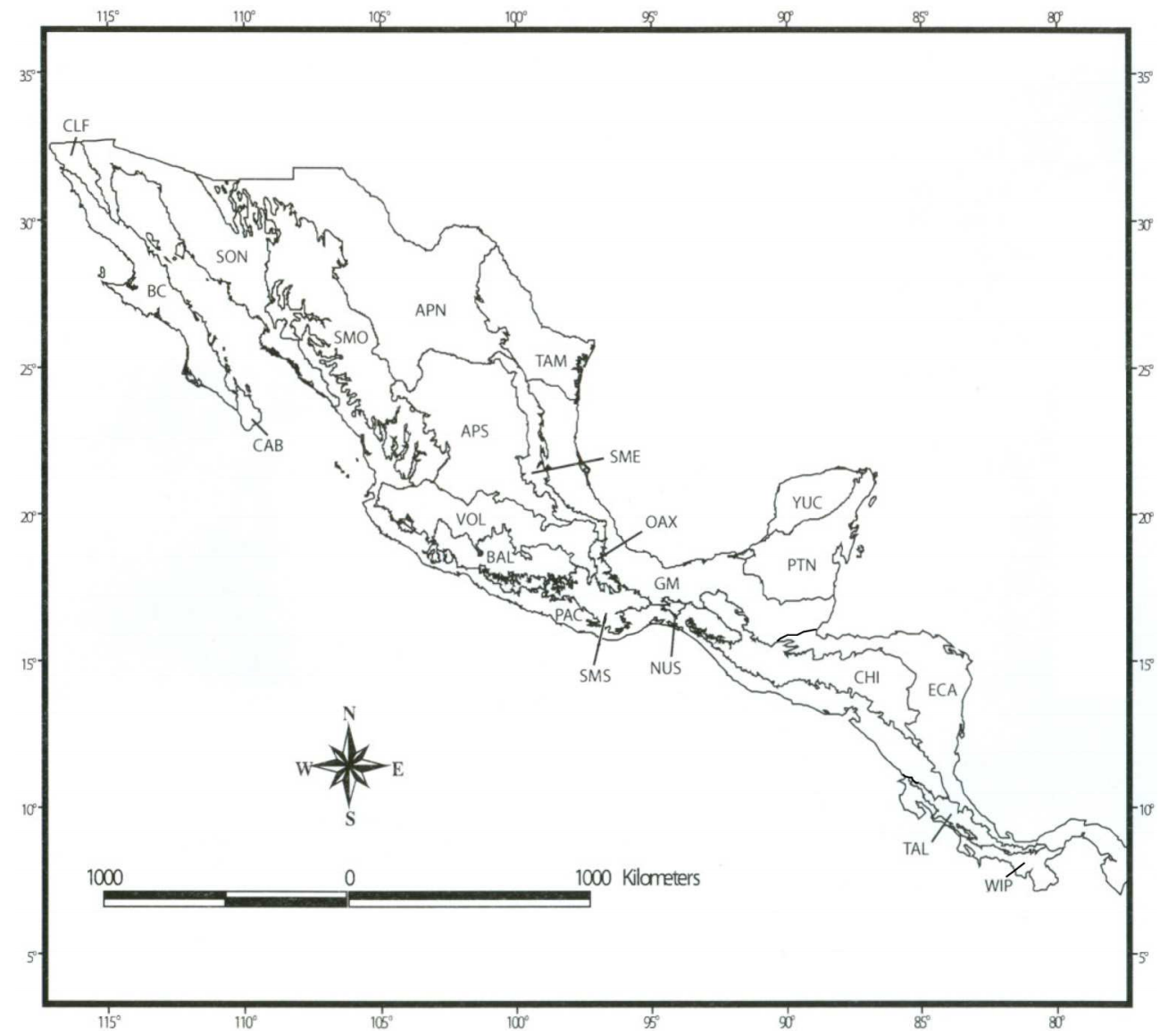

Fig. 1. The 19 biogeographic provinces of Mexico according to Arriaga et al. (1997). Abbreviations are: $\mathrm{APN}=$ Altiplano Norte, $\mathrm{APS}=$ Altiplano Sur, $\mathrm{BAL}=$ Depresión del Balsas, $\mathrm{BC}=$ Baja California, $\mathrm{CLF}=$ California, $\mathrm{CAB}=$ Del Cabo, $\mathrm{CHI}=$ Los Altos de Chiapas, $\mathrm{GM}=$ Golfo de México, NUS $=$ Soconusco, $\mathrm{OAX}=$ Oaxaca, $\mathrm{PAC}=$ Costa del Pacífico, $\mathrm{PTN}=$ Petén, $\mathrm{SME}=$ Sierra Madre Oriental, $\mathrm{SMO}=$ Sierra Madre Occidental, SMS = Sierra Madre del Sur, SON = Sonorense, TAM = Tamaulipeca, VOL = Eje Volcánico, YUC $=$ Yucatán. The provinces of Central America from Morrone (2001) are: $\mathrm{CHI}=$ Los Altos de Chiapas, ECA= Eastern Central America, WIP= Western Isthmus of Panamá, and TAL $=$ Sierra de Talamanca. 


\section{Areas of endemism in the Mexican Transition Zone}

Areas of endemism are defined by the overlapped distributions of endemic taxa (ContrerasMedina, 2006; Morrone, 1994). These kinds of areas represent the basic units in cladistic biogeography (Contreras-Medina et al., 2001); for this reason, the recognition and delimitation of areas of endemism represent a prerequisite to carry out cladistic biogeographic studies (Morrone, 1997).

Some proposals on regionalization of the Mexican Transition Zone have been suggested based on different criteria. One of the most supported schemes was that proposed by the Comisión Nacional para el Conocimiento y Uso de la Biodiversidad (CONABIO) (National Commission for the Knowledge and Use of Biodiversity, Mexico), which represents the effort of a set of several specialists on geology, vascular plants, reptiles and mammals working together to provide different proposals on regionalization of the Mexican territory with different points of view. Nineteen Mexican biogeographic provinces were recognized through this workshop (Arriaga et al., 1997). An important regionalization proposal for Central America also was made by Morrone (2001). This scheme was also followed in this study, and was also used to compare the areas of endemism found in the different revised studies on cladistic biogeography of the Mexican Transition Zone.

In the study of Espinosa et al. (2006), the parsimony analysis of endemicity (PAE) method (Rosen, 1988) was used in order to generate the 23 areas of endemism that were used later in the cladistic biogeography section of this paper. The areas of endemism were obtained by merging those areas supported by endemic (synapomorphic) species from PAE following the proposed provinces of Morrone (1994).

In many cases, the Mexican mountain ranges coincide with the areas of endemism (Fig. 2), so their recognition and delimitation represent necessary tools in future cladistic biogeographic studies. The origin and development of these mountain chains have strongly

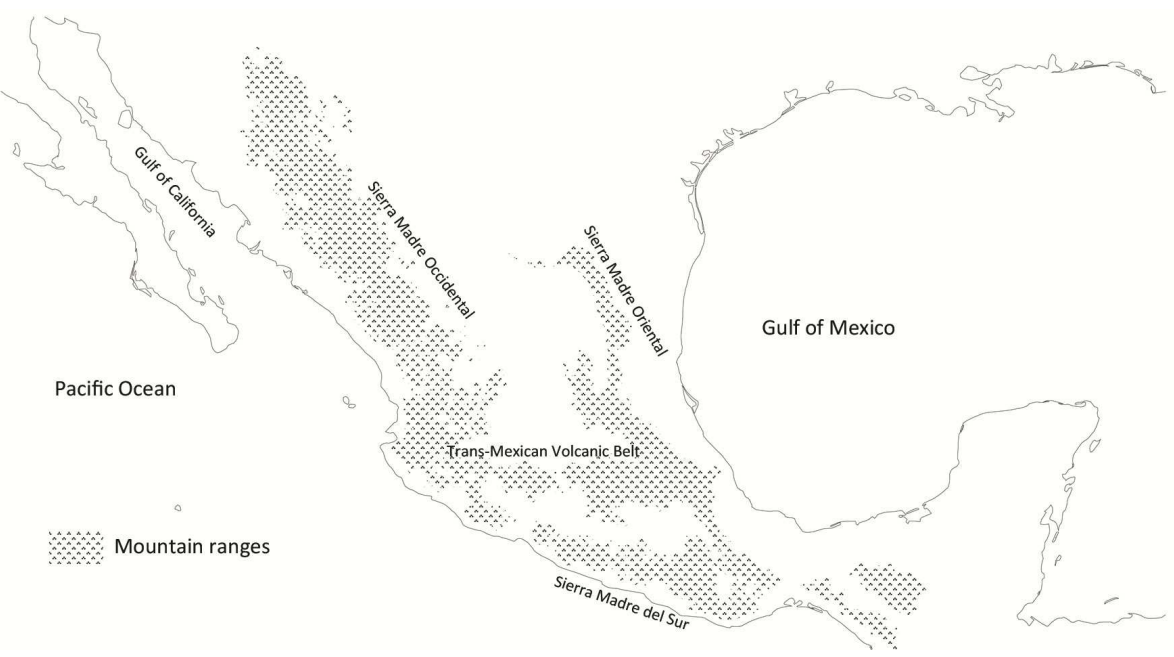

Fig. 2. The main Mexican mountain chains. 


\begin{tabular}{|c|c|c|c|c|}
\hline $\begin{array}{l}\text { Biogeographic } \\
\text { provinces }\end{array}$ & $\begin{array}{l}\text { Marshall \& } \\
\text { Liebherr (2000) }\end{array}$ & $\begin{array}{l}\text { Espinosa et al. } \\
(2006)\end{array}$ & $\begin{array}{l}\text { Flores-Villela \& } \\
\text { Goyenechea } \\
(2001)\end{array}$ & $\begin{array}{l}\text { Contreras-Medina } \\
\text { et al. (2007) }\end{array}$ \\
\hline CLF & & & & Californian \\
\hline$B C$ & & & & Baja California \\
\hline CAB & & El Cabo & & Baja California \\
\hline SON & Sonoran Desert & Sonora & Sonoran Desert & $\begin{array}{l}\text { Planicie Costera } \\
\text { del Noroeste }\end{array}$ \\
\hline SMO & $\begin{array}{l}\text { Sierra Madre } \\
\text { Occidental plus } \\
\text { Central Plateau }\end{array}$ & & $\begin{array}{l}\text { Sierra Madre } \\
\text { Occidental }\end{array}$ & $\begin{array}{l}\text { Sierra Madre } \\
\text { Occidental }\end{array}$ \\
\hline $\mathrm{APN}$ & $\begin{array}{l}\text { Sierra Madre } \\
\text { Occidental plus } \\
\text { Central Plateau }\end{array}$ & & $\begin{array}{l}\text { Chihuahuan } \\
\text { Desert }\end{array}$ & Altiplano \\
\hline APS & $\begin{array}{l}\text { Sierra Madre } \\
\text { Occidental plus } \\
\text { Central Plateau }\end{array}$ & & $\begin{array}{l}\text { Chihuahuan } \\
\text { Desert }\end{array}$ & Altiplano \\
\hline TAM & $\begin{array}{l}\text { Sierra Madre } \\
\text { Occidental plus } \\
\text { Central Plateau }\end{array}$ & & $\begin{array}{l}\text { Semiarid lands } \\
\text { of Tamaulipas }\end{array}$ & $\begin{array}{l}\text { Planicie Costera } \\
\text { del Noreste }\end{array}$ \\
\hline SME & $\begin{array}{l}\text { Sierra Madre } \\
\text { Oriental }\end{array}$ & & $\begin{array}{l}\text { Sierra Madre } \\
\text { Oriental }\end{array}$ & $\begin{array}{l}\text { Sierra Madre } \\
\text { Oriental }\end{array}$ \\
\hline VOL & $\begin{array}{l}\text { Sierra } \\
\text { Transvolcánica }\end{array}$ & & $\begin{array}{l}\text { Transvolcanic } \\
\text { Axis of Central } \\
\text { Mexico }\end{array}$ & $\begin{array}{l}\text { Serranías } \\
\text { Meridionales }\end{array}$ \\
\hline BAL & & W and E Balsas & \begin{tabular}{|l} 
Balsas \\
Depression
\end{tabular} & Balsas Basin \\
\hline SMS & $\begin{array}{l}\text { Sierra Madre } \\
\text { del Sur }\end{array}$ & Tehuantepec & $\begin{array}{l}\text { Sierra Madre del } \\
\text { Sur }\end{array}$ & $\begin{array}{l}\text { Serranías } \\
\text { Meridionales }\end{array}$ \\
\hline OAX & & $\begin{array}{l}\text { Tehuacán- } \\
\text { Cuicatlán Valley }\end{array}$ & $\begin{array}{l}\text { Transvolcanic } \\
\text { Axis of Central } \\
\text { Mexico }\end{array}$ & $\begin{array}{l}\text { Tehuacán- } \\
\text { Cuicatlán Valley }\end{array}$ \\
\hline GM & & & & $\begin{array}{l}\text { Costa del Golfo de } \\
\text { México }\end{array}$ \\
\hline PAC & & $\begin{array}{l}\text { Tuito, Papagayo, } \\
\text { Armería- } \\
\text { Coahuayana and } \\
\text { Tehuantepec }\end{array}$ & $\begin{array}{l}\text { Pacific lowlands } \\
\text { of Mexico plus } \\
\text { Balsas } \\
\text { Depression }\end{array}$ & Costa Pacífica \\
\hline NUS & & & & Soconusco \\
\hline
\end{tabular}




\begin{tabular}{|c|c|c|c|c|}
\hline $\begin{array}{l}\text { Biogeographic } \\
\text { provinces }\end{array}$ & $\begin{array}{l}\text { Marshall \& } \\
\text { Liebherr (2000) }\end{array}$ & $\begin{array}{l}\text { Espinosa et al. } \\
(2006)\end{array}$ & $\begin{array}{l}\text { Flores-Villela \& } \\
\text { Goyenechea } \\
\text { (2001) }\end{array}$ & $\begin{array}{l}\text { Contreras-Medina } \\
\text { et al. (2007) }\end{array}$ \\
\hline YUC & $\begin{array}{l}\text { Chiapan } \\
\text { Guatemalan } \\
\text { Highlands }\end{array}$ & & & Yucatán Península \\
\hline PTN & $\begin{array}{l}\text { Chiapan } \\
\text { Guatemalan } \\
\text { Highlands }\end{array}$ & & & Yucatán Península \\
\hline $\mathrm{CHI}$ & $\begin{array}{l}\text { Chiapan } \\
\text { Guatemalan } \\
\text { Highlands }\end{array}$ & & $\begin{array}{l}\text { Highlands of } \\
\text { Chiapas }\end{array}$ & $\begin{array}{l}\text { Serranías } \\
\text { Transístmicas }\end{array}$ \\
\hline ECA & $\begin{array}{l}\text { Chiapan } \\
\text { Guatemalan } \\
\text { Highlands }\end{array}$ & & $\begin{array}{l}\text { Eastern Central } \\
\text { American } \\
\text { Atlantic } \\
\text { lowlands }\end{array}$ & $\begin{array}{l}\text { Eastern Central } \\
\text { America }\end{array}$ \\
\hline WIP & $\begin{array}{l}\text { Talamancan } \\
\text { Cordillera }\end{array}$ & & $\begin{array}{l}\text { Western Central } \\
\text { American Pacific } \\
\text { lowlands }\end{array}$ & Costa Pacífica \\
\hline TAL & $\begin{array}{l}\text { Talamancan } \\
\text { Cordillera }\end{array}$ & & Talamanca ridge & \\
\hline
\end{tabular}

NOTES: When the same name of an area of endemism appears in two or more cells, it means that this area in this particular study is very large and includes two or more biogeographic provinces. Empty cells mean that the biogeographic province was not included or considered in our study.

Table 1. Comparison among the areas of endemism of the Mexican Transition Zone used in some of the studies cited in this chapter, in relation to the biogeographic provinces of Arriaga et al. (1997) and Morrone (2001).

influenced the geographic distribution of the biota of the MTZ. The geological evolution of Mexico and Central America during the Cretaceous and Cenozoic has had a significant influence on the processes controlling the composition of their biota (Cevallos-Ferriz \& González-Torres, 2005). The primary geological events shaping Mexico and Central America during these time intervals include the following: (1) the development of large magmatic provinces (Sierra Madre Occidental, Trans-Mexican Volcanic Belt, and Sierra Madre del Sur); (2) the fragmentation and displacement of continental segments including the opening of the Gulf of California (the separation of the Baja California Peninsula from the mainland) and the displacement of the Chortis Block to northern Central America; (3) the marine regression that outlined the current shape of Mexico; and (4) the formation and rise of an eastern orogenic belt known as the Sierra Madre Oriental (Cevallos-Ferriz \& GonzálezTorres, 2005; Ortega-Gutiérrez et al., 1994).

In Table 1 (above), two additional studies merit comment. Liebherr (1991) did not name areas of endemism, but designated them by letters, making it difficult to compare his areas with those of other authors. Rosen (1978) identified very small areas of endemism, only 
including small parts of the MTZ - these areas were mainly in Chiapas, eastern Central America, Petén, and Golfo de México.

\section{Cladistic biogeography studies in the Mexican Transition Zone}

Rosen (1978) was the first to apply a cladistic biogeography approach to the MTZ. In his biogeographic research, the author included the phylogenies of two fresh water fish of the genera Heterandria and Xiphophorus. Rosen (1978) recognized three coincidences of historical relationships, indicating the existence of a common ancestral distributional area that had been fragmented twice and that currently constitutes the basins of the Bravo River (in northern Mexico), the Pánuco River (in northeastern Mexico), and the Grijalva River (on the border between Mexico and Guatemala).

Another pioneering cladistic biogeographic study in the MTZ is that of Liebherr (1991). This author analyzed the history the mountain biota based on the phylogenies of two Coleoptera genera (Elliptoleus and Calathus). The complexity of the geologic history of southern Mexico is noted in the general area cladogram obtained, showing an ancient primary fragmentation that separated extra-tropical from tropical biota. Liebherr (1991) obtained a first clade that was divided in two subgroups, the first formed by the Sierra Madre Oriental and the second by the Sierra Madre Occidental and part of the Mexican Plateau. The tropical clade included the southern portions of the Sierra Madre Occidental, Sierra Madre Oriental and other Mexican mountain chains such the Sierra Madre del Sur and the Trans-Mexican Volcanic Belt.

Marshall \& Liebherr (2000) published a cladistic biogeography study applying BPA and Assumption 0 methods based on 33 taxa (beetles, reptiles, fish and one plant genus) and using nine areas of endemism; they obtained four general area cladograms, one with BPA and three with Assumption 0. The congruence among these cladograms is shown in the relationships among the Arizona Mountains plus the Sierra Madre Occidental in one clade, and the Sierra Madre del Sur plus the Trans-Mexican Volcanic Belt related with the Chiapan-Guatemalan Highlands in another clade. Unfortunately, their approach included methodological confusion regarding the Assumption 0: the missing taxa option (or missing areas) in the matrix is treated by them as ' 0 ', indicating the lack of information regarding a taxon's occurrence. However, the Assumption 0 approach considers missing areas to be uninformative, as well as the other two assumptions (1 and 2) in a component analysis method (Morrone, 1998), so missing areas are located in all possible positions in the resolved area cladograms. Assumption 0 in BPA implies that areas inhabited by a widespread taxon are considered as sister areas (Morrone, 1997).

Flores-Villela \& Goyenechea (2001) used 10 animal taxa in their biogeographical study (beetles, lizards, snakes and frogs) distributed in 13 areas of endemism; the method of reconciled trees implementing assumptions 0,1 , and 2 was applied in this study. The authors obtained six general area cladograms, but they did not achieve a consistent pattern of relationships among these cladograms. They concluded that each cladogram could only explain portions of the geographic history of the taxa studied, and that the results obtained were due to the geological complexity of the area under study.

Espinosa et al. (2006) generated hypotheses on the historical biogeography of tropical Mexico using the flowering plant genus Bursera. This study was based on the geographic distribution of 104 species in this genus analyzed with the BPA method. The consensus 
general area cladogram obtained was formed by two main clades: the first included different areas of the Greater Antilles, and the second 12 Mexican areas of endemism. In this second clade all the areas located on the Pacific slope are included in one group, and the basal branch of this clade is constituted by the unique area located on the Gulf of Mexico slope. This general area cladogram shows the proposed historical relationships among tropical areas of Mexico.

The study of Contreras-Medina et al. (2007) was based on 81 gymnosperm species of the genera Ceratozamia, Dioon and Pinus, applying BPA and paralogy-free subtrees methods. In the case of the Mexican provinces, the unique relationship of both general area cladograms was the Mexican Plateau plus the Sierra Madre Oriental related with the Sierra Madre Occidental; the lowland provinces were mostly related, as in the study of Espinosa et al. (2006) with Bursera. Contreras-Medina and collaborators considered that both peninsulas of Mexico (Baja California and Yucatán) had a different history in relation to the continental portion of the country.

\section{Conclusions}

The MTZ represents a challenge for cladistic biogeography, due (in part) to its location at the boundaries between the Nearctic and Neotropical biogeographic regions, allowing the mixture of different biotic elements (Escalante et al., 2007), as suggested by previous studies from panbiogeographic approach (Contreras-Medina \& Eliosa-León, 2001; Escalante et al. 2004; Morrone \& Márquez, 2001). Also from a tectonic perspective, this region has formed through the convergence of three tectonic plates (North American, Cocos, and Caribbean), contributing to its geological complexity (Ortega et al., 1994).

After discussing the differences derived from applying different methods to carry out cladistic biogeographic analyses, Morrone \& Carpenter (1994) concluded that when the data are "clean" (including few widespread taxa, redundant distributions, and missing areas), the results obtained using different methods are consistent. Some MTZ vicariance patterns, particularly those influenced by widespread taxa, redundant distributions and missing areas, appear to be ambiguous or the result of biogeographic noise. It remains difficult to select appropriate cladistic biogeographic methods because all have advantages and disadvantages, and all of them have been criticized (Morrone, 2009). One suggestion is to apply several methods and compare their differences and similarities (i.e., ContrerasMedina et al., 2007).

In addition, differences among the size and number of areas of endemism used in the different studies carried out in the MTZ make the search for congruent patterns of area relationships difficult. Unfortunately, it is not possible to make generalizations and comparisons among some clades obtained from the different studies commented upon here because, for example, some of the areas included in a clade of one study were not included in another, or in some studies wider units of analysis (areas of endemism) were used than those used in other studies. In some cases, different studies can be complementary, as occurred in the case of Marshall and Liebherr (2000) and Espinosa et al. (2006): the former was based mainly on mountainous taxa, whereas the latter was based mainly on lowland taxa. Notwithstanding, incongruent patterns should not be taken as signs of dispersal; they 
may be the result of more than one vicariance pattern and/or to the reticulate biogeographic history in areas of endemism (Morrone, 2009).

A much needed analysis in the near future is consensus on the unification of areas of endemism in the MTZ. This will greatly strengthen cladistic biogeography interpretation, as well as the generation of new morphological and molecular phylogenies of the biota of the MTZ. Both activities represent a challenge, but it is the only way to advance in the comprehension of the complicated historical biogeography of this region. As Flores-Villela \& Goyenechea (2001) noted in the title of their paper, we are still "seeking the lost pattern of the biota inhabiting the Mexican Transition Zone."

\section{Acknowledgments}

Dragana Manestar invited us to present this contribution. David Espinosa and Othón Alcántara assisted us with the figures and with useful comments on the manuscript. Lawrence E. Stevens made useful suggestions to this chapter. Finantial support was given by DGAPA-PAPIIT IN221711.

\section{References}

Álvarez, E. \& Morrone, J.J. (2004). Propuesta de áreas para la conservación de aves de México, empleando herramientas panbiogeográficas e índices de complementariedad. Interciencia Vol. 29, pp. 112-120, ISSN 0378-1844

Aguilar-Aguilar, R.; Contreras-Medina, R. \& Salgado-Maldonado, G. (2003). Parsimony Analysis of Endemicity (PAE) of Mexican hydrological basins based on helminth parasites of freshwater fishes. Journal of Biogeography, Vol. 30, pp. 1861-1872, ISSN 0305-0270

Arriaga, L.; Aguilar, C.; Espinosa, D. \& Jiménez, R. (eds). (1997). Regionalización ecológica y biogeográfica de México. Worshop developed in the Comisión Nacional para el Conocimiento y Uso de la Biodiversidad (CONABIO), November 1997.

Brooks, D.R. (1990). Parsimony analysis in historical biogeography and coevolution: Methodological and theoretical update. Systematic Zoology, Vol. 39, pp 14-30, ISSN 0039-7989

Brooks, D.R.; Van Veller, M.G.P. \& McLennan, D.A. (2001). How to do BPA, really. Journal of Biogeography, Vol. 28, pp. 345-358, ISSN 0305-0270

Cevallos-Ferriz, S.R.S. \& González-Torres, E. A. (2005). Geological setting and phytobiodiversity in Mexico. In: Studies on Mexican Paleontology, F. Vega, T.G. Nyborg, M.C. Perrilliat, M. Montellano-Ballesteros, S. Cevallos-Ferriz \& S. QuirozBarroso (Eds.). Springer-Verlag. Dordrecht, The Netherlands. pp. 1-18, ISBN 14020-3882-8

Contreras-Medina, R. (2006). Los métodos de análisis biogeográfico y su aplicación a la distribución de las gimnospermas mexicanas. Interciencia Vol. 31, No. 3, pp. 176182, ISSN 0378-1844

Contreras-Medina, R. \& Eliosa-León, H. (2001). Una visión panbiogeográfica preliminar de México, In: Introducción a la Biogeografía en Latinoamérica: conceptos, teorías, métodos y aplicaciones, J. Llorente \& J.J. Morrone (Eds.), 197-211, Universidad Nacional Autónoma de México-CONABIO, México, D. F. ISBN 968-36-9463-2 
Contreras-Medina, R.; Morrone, J.J. \& Luna-Vega, I. (2001). Biogeographic methods identify gymnosperm biodiversity hotspots. Naturwissenschaften Vol. 88, No. 10, pp. 427430, ISSN 0028-1042

Contreras-Medina, R.; Luna-Vega, I. \& Morrone, J.J. (2007). Gymnosperms and cladistic biogeography of the Mexican Transition Zone. Taxon Vol. 56, No. 3, pp. 905-915, ISSN 0040-0262

Craw, R. (1988). Continuing the synthesis between panbiogeography, phylogenetic systematics and geology as illustrated by empirical studies on the biogeography of New Zealand and the Chatham Islands. Systematic Zoology Vol. 37, pp. 291-310, ISSN 1096-0031

Crisci, J. V. ; Katinas, L. \& Posadas, P. (2000). Introducción a la teoría y práctica de la biogeografía histórica. Buenos Aires, Sociedad Argentina de Botánica, ISBN 987-97012-4-0 (English translation: 2003, Historical biogeography: An introduction, Cambridge, Mass., Harvard University Press).

Croizat, L. (1958). Panbiogeography. Published by the author. Caracas. 1731 p. ISBN 9780854860340

Croizat, L. (1964). Space, time, and form: The biological synthesis. Published by the author. Caracas. ISBN 978-0854860364

Escalante, T.; Rodríguez, G. \& Morrone, J.J. (2004). The diversification of the Nearctic mammals in the Mexican transition zone: A track analysis. Biological Journal of the Linnean Society, Vol. 83, pp. 327-339, ISSN 10958312

Escalante, T.; Rodríguez, G.; Cao, N.; Ebach, M.C. \& Morrone, J.J. (2007). Cladistic biogeographic analysis suggests an early Caribbean diversification in Mexico. Naturwissenschaften, Vol. 94, pp. 561-565, ISSN 0378-1844

Espinosa, D.; Morrone, J.J. \& Llorente, J. (2006). Historical biogeographical patterns of the species of Bursera (Burseraceae) and their taxonomic implications. Journal of Biogeography, Vol. 33, pp. 1945-1958, ISSN 0305-0270

Espinosa, D. \& Llorente, J. (1993). Fundamentos de biogeografías filogenéticas. Universidad Nacional Autónoma de México -CONABIO, México, D. F. ISBN 968-36-2984-9

Espinosa, D.; Morrone, J.J.; Aguilar, C. \& Llorente, J. (2000). Regionalización biogeográfica de México: provincias bióticas. In: Biodiversidad, taxonomía y biogeografía de artrópodos de México: hacia una síntesis de su conocimiento, J. Llorente, E. González \& N. Papavero (Eds.), Volume 2, Universidad Nacional Autónoma de MéxicoCONABIO, México, D. F., pp. 61-94. ISBN 978-9683648570

Espinosa, D.; Llorente, J. \& Morrone, J.J. (2006). Historical biogeographical patterns of the species of Bursera (Burseraceae) and their taxonomic implications. Journal of Biogeography Vol. 33, pp. 1945-1958, ISSN 0305-0270

Flores-Villela, O. \& Gerez, P. (1994) Biodiversidad y conservación en México: vertebrados, vegetación y uso de suelo. Second Edition. Universidad Nacional Autónoma de México, México, D. F. ISBN 968-36-3992-5

Flores-Villela, O. \& Goyenechea, I. (2001). A comparison of hypotheses of historical area relationships for Mexico and Central America, or in search for the lost pattern. Pp. 171--181 In: Johnson, J. D., Webb, R. G. \& Flores-Villela, O. (eds.), Mesoamerican herpetology: Systematics, zoogeography and conservation. University of Texas, El Paso, Texas, ISBN 79968-0533 
Halffter, G. (1987). Biogeography of the montane entomofauna of Mexico and Central America. Annual Review of Entomology, Vol. 32, pp. 95-114, ISSN 0066-4170

Hennig, W. (1966). Phylogenetic systematics. University of Illinois Press, Urbana IL, 280 p., ISBN 978-025-2068-140

Humphries, C.J. \& Parenti, L.R. (1999). Cladistic biogeography. Oxford University Press, New York, ISBN 019-854818-4

Kluge, A.G. (1988). Parsimony in vicariance biogeography: A quantitative method and a Greater Antillean example. Systematic Zoology Vol. 37, pp. 315-328, ISSN 0039-7989

Liebherr, J.K. (1991). A general area cladogram for montane Mexico based on distributions in the Platynine genera Elliptoleus and Calathus (Coleoptera: Carabidae). Proceedings of the Entomological Society of Washington, Vol. 93, No. 2, pp. 390-406, ISSN 00138797

Luna-Vega, I.; Morrone, J.J.; Alcántara, O. \& Espinosa, D. (2001). Biogeographical affinities among Neotropical cloud forests. Plant Systematics and Evolution Vol. 228, pp. $229-$ 239, ISSN 0378-2697

Luna-Vega, I. \& Contreras-Medina, R. (2010). Plant biodiversity hotspots and biogeographic methods. In: Biodiversity hotspots, Rescigno, V. \& S. Maletta (Eds.), 181-191, NovaScience Publishers, New York. ISBN 978-1-60876-458-7

Marshall, C.J. \& Liebherr, J.K. (2000). Cladistic biogeography of the Mexican transition zone. Journal of Biogeography, Vol. 27, pp. 203-216, ISSN 0305-0270

Morrone, J.J. (1994). On the identification of areas of endemism. Systematic Biology Vol. 43, pp. $438-441$, ISSN $1063-5157$

Morrone, J.J. (1997). Biogeografía cladística: conceptos básicos. Arbor Vol. 158, pp. 373-388, ISSN 0210-1963

Morrone, J.J. (2001). Biogeografía de América Latina y el Caribe. SEA y M \& T Tesis, Zaragoza, Spain, ISBN 84-922495-4-4

Morrone, J. J. (2005). Cladistic biogeography: identity and place. Journal of Biogeography Vol. 32 , pp. 1281-1284, ISSN 0305-0270

Morrone, J.J. (2009). Evolutionary biogeography: An integrative approach with case studies. Columbia University Press, New York, ISBN 978-0-231-14378-3

Morrone, J. J. \& Crisci, J. V. (1995). Historical biogeography: Introduction to methods. Annual Review of Ecology and Systematics Vol. 26, pp. 373-401, ISSN 0066-4162

Morrone, J.J. \& Márquez, J. (2001). Halffter's Mexican transition zone, beetle generalized tracks, and geographical homology. Journal of Biogeography Vol. 28, pp. 635-650, ISSN 0305-0270

Morrone, J.J. \& Escalante, T. (2002). Parsimony analysis of endemicity (PAE) of Mexican terrestrial mammals at different area units: When size matters. Journal of Biogeography Vol. 29, pp. 1095-1104, ISSN 0305-0270

Morrone, J. J. \& Gutiérrez, A. (2005). Do fleas (Insecta: Siphonaptera) parallel their mammal host diversification in the Mexican transition zone? Journal of Biogeography Vol. 32, pp. 1315-1325, ISSN 0305-0270

Morrone, J. J.; Espinosa, D. \& Llorente, J. (1996). Manual de biogeografía histórica. Universidad Nacional Autónoma de México, México, D. F. ISBN 968-36-4842-8

Morrone, J. J.; Espinosa, D.; Aguilar, C. \& Llorente, J. (1999). Preliminary classification of the Mexican biogeographic provinces: A parsimony analysis of endemicity based on 
plant, insect, and bird taxa. Southwestern Naturalist Vol. 44, pp. 508-515, ISSN 0038-4909

Morrone, J.J. \& Carpenter, J.M. (1994). In search of a method for cladistic biogeography: An empirical comparison of component analysis, Brooks parsimony analysis, and three-area statements. Cladistics, Vol. 10, No. 2, (June 1994), pp. 99-153, ISSN 10960031

Myers, N.; Mittermeier, R.A.; Mittermeier, C.G.; da Fonseca, G.A.B. \& Kent, J. (2000). Biodiversity hotspots for conservation priorities. Nature Vol. 403, pp. 853-858, ISSN 0028-0836

Nelson, G. \& Ladiges, P.Y. (1995). TAX: MSDOS computer programs for systematics. Published by the authors, New York and Melbourne.

Nelson, G. \& Ladiges, P.Y. (1996). Paralogy in cladistic biogeography and analysis of paralogy-free subtrees. American Museum Novitates Vol. 3167, pp. 1-58, ISSN 00030082

Nelson, G. \& Platnick, N.I. (1981). Systematics and biogeography: Cladistics and vicariance. Columbia University Press, New York, ISBN 0-231-04574-3

Ortega-Gutiérrez, F.; Sedlock, R. L. \& Speed, R. C. (1994). Phanerozoic tectonic evolution of Mexico. In: Phanerozoic evolution of North American continent-ocean transitions, R.C. Speed (Ed.), pp. 265-306, The Geological Society of America, Boulder, Colorado. ISBN 978-0813753058

Page, R.D.M. \& Lydeard, C. (1994). Towards a cladistic biogeography of the Caribbean. Cladistics, Vol. 10, No. 1, (March 1994), pp. 21-41, ISSN 1096-0031

Rosen, D.E. (1978). Vicariant patterns and historical explanation in biogeography. Systematic Zoology Vol. 27, pp. 159-188, ISSN 0039-7989

Sclater, P.L. (1858). On the geographical distribution of the Class Aves. Journal of the Linnean Society of London, Zoology, Vol. 2, pp. 130-145, ISSN 03682935

Siddall, M.E. \& Perkins, S.L. (2003). Brook parsimony analysis: a valiant failure. Cladistics Vol. 19, pp. 554-564, ISSN 1096-0031

Van Veller, M. G. P. \& Brooks, D.R. (2001). When simplicity is not parsimonious: a priori and a posteriori methods in historical biogeography. Journal of Biogeography Vol. 28, pp. 345-358, ISSN 0305-0270 


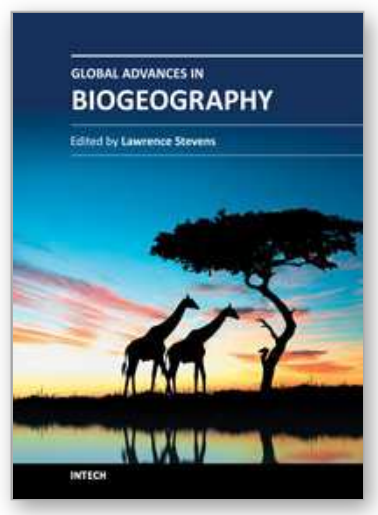

\author{
Global Advances in Biogeography \\ Edited by Dr. Lawrence Stevens
}

ISBN 978-953-51-0454-4

Hard cover, 360 pages

Publisher InTech

Published online 30, March, 2012

Published in print edition March, 2012

Global Advances in Biogeography brings together the work of more than 30 scientific authorities on biogeography from around the world. The book focuses on spatial and temporal variation of biological assemblages in relation to landscape complexity and environmental change. Global Advances embraces four themes: biogeographic theory and tests of concepts, the regional biogeography of individual taxa, the biogeography of complex landscapes, and the deep-time evolutionary biogeography of macrotaxa. In addition, the book provides a trove of new information about unusual landscapes, the natural history of a wide array of poorly known plant and animal species, and global conservation issues. This book is well illustrated with numerous maps, graphics, and photographs, and contains much new basic biogeographical information that is not available elsewhere. It will serve as an invaluable reference for professionals and members of the public interested in global biogeography, evolution, taxonomy, and conservation.

\title{
How to reference
}

In order to correctly reference this scholarly work, feel free to copy and paste the following:

Isolda Luna-Vega and Raúl Contreras-Medina (2012). Contributions of Cladistic Biogeography to the Mexican Transition Zone, Global Advances in Biogeography, Dr. Lawrence Stevens (Ed.), ISBN: 978-953-51-0454-4, InTech, Available from: http://www.intechopen.com/books/global-advances-in-biogeography/contributions-ofcladistic-biogeography-to-the-mexican-transition-zone

\section{INTECH}

open science | open minds

\author{
InTech Europe \\ University Campus STeP Ri \\ Slavka Krautzeka 83/A \\ 51000 Rijeka, Croatia \\ Phone: +385 (51) 770447 \\ Fax: +385 (51) 686166 \\ www.intechopen.com
}

\author{
InTech China \\ Unit 405, Office Block, Hotel Equatorial Shanghai \\ No.65, Yan An Road (West), Shanghai, 200040, China \\ 中国上海市延安西路65号上海国际贵都大饭店办公楼405单元 \\ Phone: +86-21-62489820 \\ Fax: +86-21-62489821
}


(C) 2012 The Author(s). Licensee IntechOpen. This is an open access article distributed under the terms of the Creative Commons Attribution 3.0 License, which permits unrestricted use, distribution, and reproduction in any medium, provided the original work is properly cited. 